\title{
A Financial Ratio Analysis of Oil and Gas Private Company in Indonesia: Before and After Declining the Oil Production
}

\author{
Wiwiek Mardawiyah Daryanto ${ }^{1 *}$, Sudarmawan Samidi ${ }^{2}$ \\ ${ }^{1,2}$ Sekolah Tinggi Manajemen Ipmi, Jakarta
}

\begin{abstract}
A B S T R A C T
As we know that the oil and gas industry is a huge industry and a big contributor to government revenue. However, a significant decline in government revenues from this sector is in 2014 by $14.11 \%$ to $4.46 \%$ in 2015 , and in 2016 the value is not too far from the previous year that is $4.58 \%$. This is due to the decline in world oil prices and also the decline in production of Indonesian private oil and gas companies. The purpose of this study is to analyze the financial performance of Indonesia's private oil and gas company before and afte $r$ declining the national oil and gas production. The data were collected from financial report of PT. Medco Internasional, Tbk and divided into two periods. The period before the decline in production from 2011 to 2013, and after the decline in production from 2014 to 2016. Financial ratio analysis (FRA) and paired sample t-test were used to analyze the data. The results show that Indonesia's private oil and gas company is still in good performance even in one year suffered considerable losses. The value of cash ratio, inventory turnover, and collection period significantly different before and after the decline in oil and gas production. The authors believe that findings will be helpful for managers who continuously attempt to explore opportunities to provide a higher return.
\end{abstract}

ART ICLE INFO

C 2018 IJBS, All rights reserved.

Keywords:

Financial Performance,

Profitability,

Solvency,

Liquidity,

Oil and Gas Company.

Copyright $(\odot$ 2018Authors. This is an open access article distributed under the Creative Commons Attribution License, which permits unrestricted use, distribution, and reproduction in any medium, provided the original work is properly cited.

\section{INTRODUCTION}

The world contains great amount of nonconventional oil, and various oil substitutes. In any case, the speed of the decrease in the production of conventional oil makes it probable that these non-conventional sources cannot come on-stream sufficiently quick to completely adjust (Bentley, 2002). Over the years, there has been a developing negative supposition towards the oil and gas 
industry and 'big energy'. The pattern towards renewable and alternatives energy is likewise another threat to traditional oil and gas companies. Nonetheless, the oil and gas industry are still remarkably successful and still experiences massive growth (Dutta, 2013).

At this moment, crude oil is one of the most present and essential resource in everyday life. The oil business is a standout amongst the most powerful branches in the world of economy. More than four billion metric tons of oil is produced worldwide annually. Oil and gas companies are among the biggest corporation around the world. Among the top ten companies worldwide based on revenue, six are in the oil business (Statistica, 2016).

The biggest volumes of products of the oil and gas industry are fuel oil and gasoline (petrol). Petroleum is the essential material for a huge number of chemical products, including pharmaceuticals, fertilizers, solvents and plastics (Dutta, 2013). Oil companies are starting to assemble themselves back that cost have recovered from their lowest levels in a decade. A barrel of WTI crude has been lounging around $\$ 50$ a barrel all year, up to from $\$ 30$ in early 2016. Rising prices, in addition to cost cuts and the revenue produced from side projects, is beginning to help many companies to turn a benefit once more (Gensler, 2017).
In the case of oil price, in accordance to PWC (2017) oil and gas industry has experienced dramatic volatility. Data reveal that from its peak in mid2008 the price is US $\$ 145$ per barrel, the oil price collapsed by more than $70 \%$ and ended in 2008 at US $\$ 40$ per barrel following the global financial crisis. There was a significant increase at US $\$ 79,4$ per barrel in 2010 and a further increased to 112,73 per barrel. Meanwhile, it falls down to US $\$ 49,46$ per barrels in 2016 (Ministry of Energy and Mineral Resources of Republic of Indonesia, 2016). According to Wood Mackenzie analyse in 2016, there has been decreasing of $30 \%$ investment expenditure compared in the year of 2015. These shows progressively that an investment of oil and gas globally in 2016 only achieved 56\% rather than in 2014 (SKK Migas, 2016).

From the figure 1 above, it shows the information about the performance of crude oil and gas in Indonesia from 1996 to 2020 . The instability of oil price has been influenced by the limited production and high demand (Daryanto, Nurfadilah, 2018). The highest amount of oil and gas production was in 1974 to 1977. The lowest amount of oil and gas production is in the year 2000 to 2014 .

The present study is focusing on oil and gas industry. It is shroud one of biggest energy company in Indonesia in the period of 2012 to 2016. The purpose of this study is to measure the

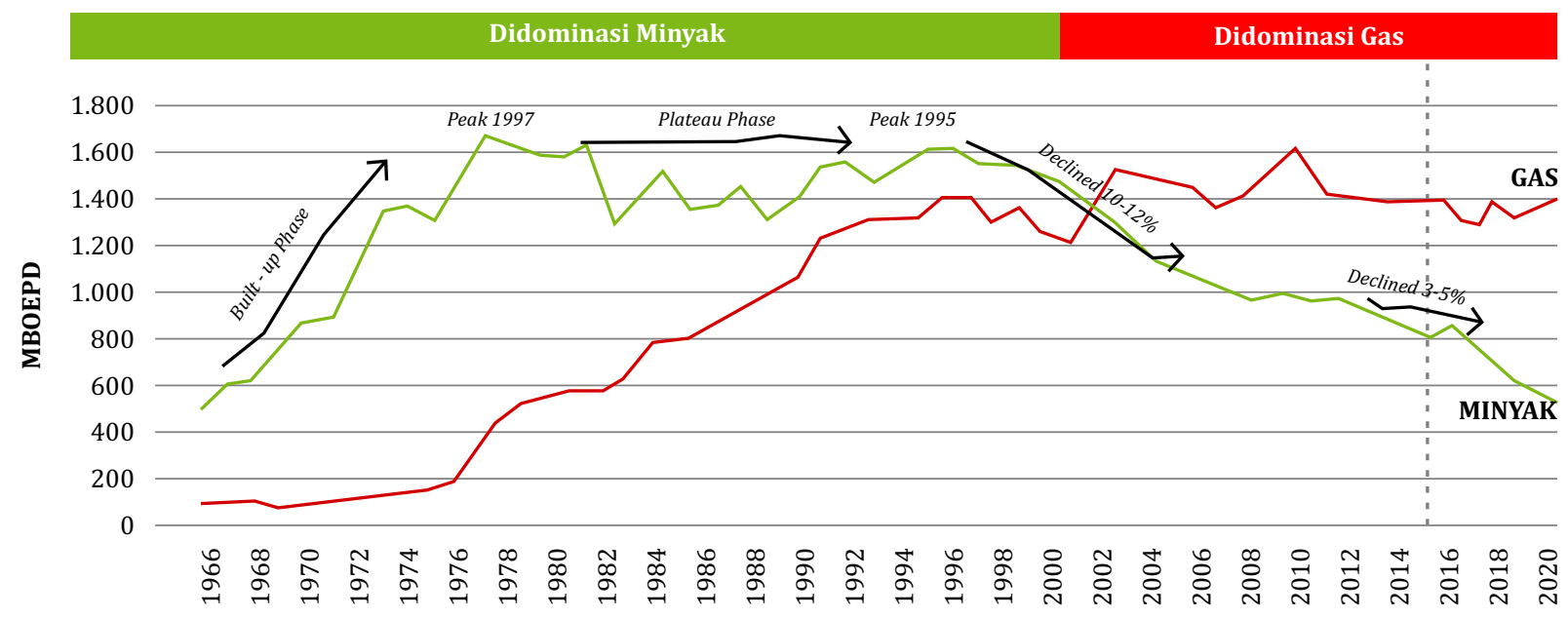

Source: SKK Migal Annual Report (2016).

Figure 1. Performance of Crude Oil and Gas 
level performance of oil and gas industry in Indonesia using financial ratio analysis. The outcome of this study will facilitate the student and academicians to assess the financial performance of the company and to make learning more practical and understood. This study also will be beneficial for managers to evaluate the performance of their company before making decisions.

This study is organized into seven sections. Section one captures the introduction, section two highlight the performance of Indonesia's oil and gas industry, section three highlight the literature review about previous researcher, section four for discuss the methodology, section five discuss the finding and analysis, section six highlight the implication and section seven captures the conclusion.

\section{LITERATURE REVIEW}

\section{Development of Oil and Gas Industry in Indonesia}

The advancement of current oil and gas in Indonesia started when the first drilling conducted in 1871 in the village of Maja, Majalengka, West Java by Dutch businessman named January Reeric, later the business closed. The primary disclosure of oil assets in Indonesia occurred in 1883 that oil field and Ponds near Pangkalan Brandan Said by a Dutchman named AG Zeijlker. After the war of independence in the age of revolution, physically assumed control over the oil establishment by the Indonesian Government. In 1945 built PT. National Oil People whi in 1954 turned out to be North Sumatra Oil Mining Company. After several time changed its name, in 1968 P.N. Permina merged into P.N. Pertamina and became the sole national oil company (Industri migas, 2011).

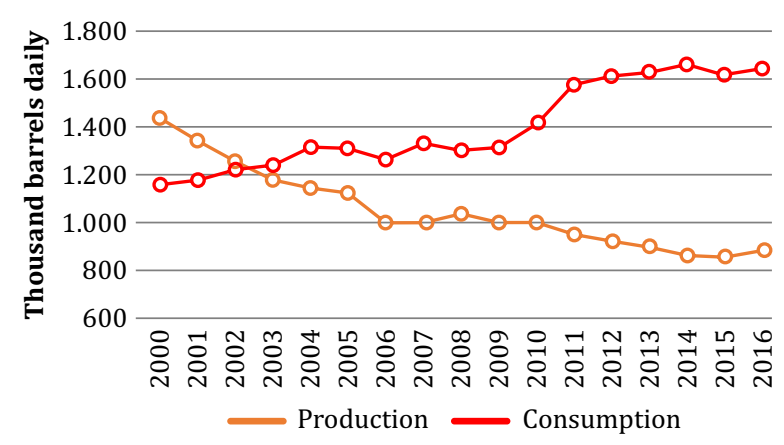

Source: PWC Investment and Taxation Guide (2017)

Figure 2. Indonesian Oil Production and Consumption
Indonesia holds proven oil stores of 3.7 billion barrels and ranked in the top 20 of the world's oil producers. Nonetheless, declining oil production and expanded utilization has resulted in Indonesia being net oil importer since 2004. This factor, along with high oil cost before 2015, drove the Government to progressively scale back the fuel subsidy during 2009-2014 (PWC, 2017). With the current energy circumstance of divergence in energy reserves availability, consumption and infrastructure. In 2006, PT. Medco Power Indonesia, owned by Saratoga Power and Medco Energi Internasional Tbk, awarded the development of World's largest single geothermal contract in Sarulla, North Sumatra (IPP Journal, n.d). As the largest national listed energy company in Indonesia, the company has increased its effective interest in PT. Medco Power Indonesia from 49\% to $88.62 \%$, with $11.38 \%$ remaining share held by International Financial Corporation unchanged. PT. Medco Power Indonesia moving forward to get renewable energy resources as the future plan to boost local economic development without bringing longterm potential disadvantages to the environment. (Medcopower, 2017).

Indonesia also had been the part of The Organization of the Petroleum Exporting Countries (OPEC) is a permanent, intergovernmental Organization with Iran, Iraq, Kuwait, Saudi Arabia, Venezuela, Qatar, Libya, United Arab Emirates, Algeria, Nigeria, Equador, Angola, Gabon and Equatorial Guinea. OPEC's objectives to co-ordinate and bind together oil strategies among member countries, with a specific end goal to secure fair and stable prices for petroleum producers, an efficient economic and regular supply of petroleum to consuming nations, and a fair return on capital to those investing in the industry. Indonesia joined OPEC in 1962 but suspended its membership in January 2009, reactivated in January 2016 but decided to suspend it again in November 2016 (OPEC, 2016). On its substance, Indonesia shows up a far-fetched expansion to the oil exporters cartel given that the country expends about twice as much rough as it pumps in this manner putting it in a general sense inconsistent with OPEC's historic mission of maintaining a high price (Georgescu et al, 2016). 


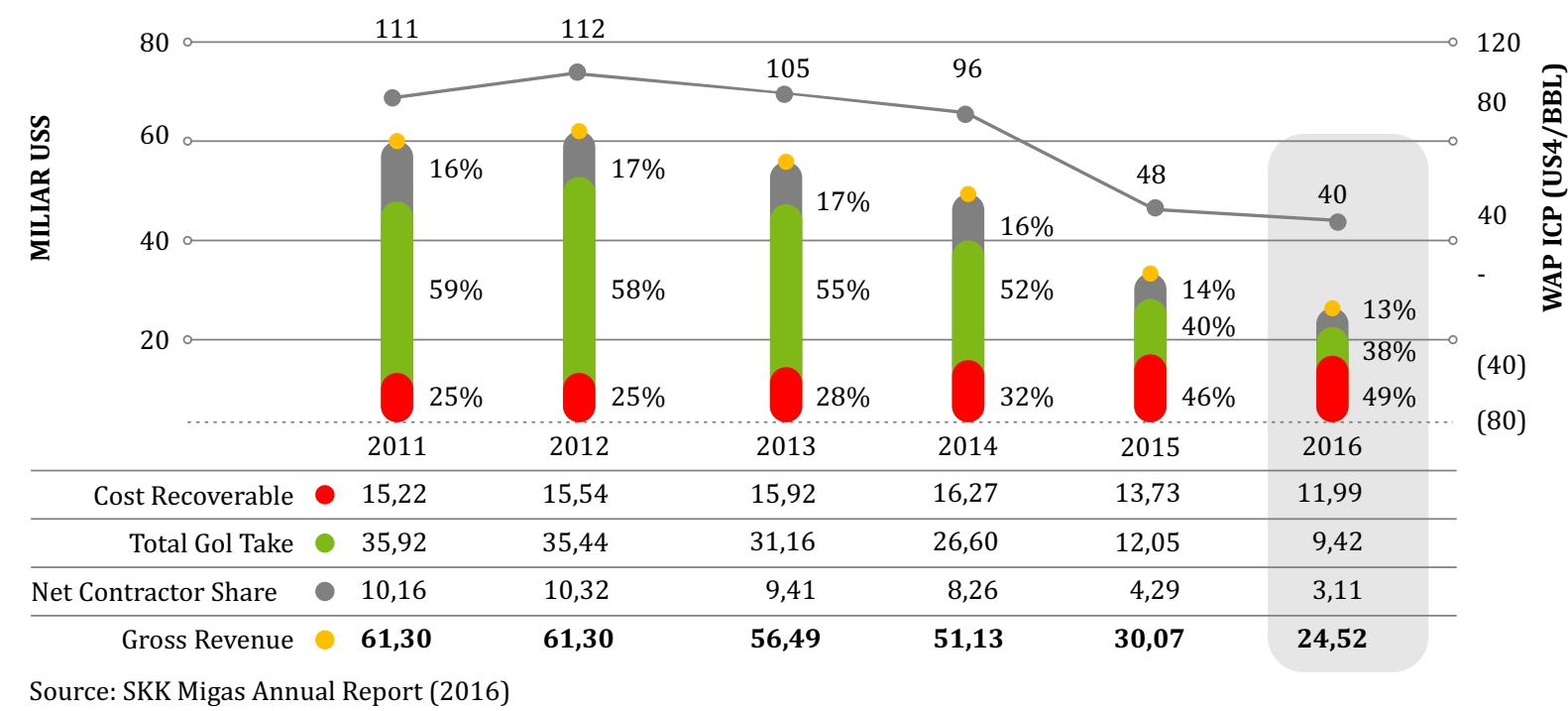

Figure 3. Income Distribution Oil and Gas Industry

Table 1. Key Indicator

\begin{tabular}{|l|r|r|r|r|r|r|}
\hline Indicator & $\mathbf{2 0 1 1}$ & $\mathbf{2 0 1 2}$ & $\mathbf{2 0 1 3}$ & $\mathbf{2 0 1 4}$ & $\mathbf{2 0 1 5}$ & $\mathbf{2 0 1 6}$ \\
\hline Reserves & \multicolumn{7}{|l|}{} \\
\hline Oil (Million Barrels) & 7,730 & 7,410 & 7,550 & 7,370 & 7,442 & 7,250 \\
\hline Proven & 4,040 & 3,740 & 3,690 & 3,620 & 3,692 & 3,306 \\
\hline Potential & 3,690 & 3,670 & 3,860 & 3,750 & 3,750 & 3,944 \\
\hline${ }^{* *}$ Gas (TFC) & 152.89 & 150.70 & 150.39 & 149.30 & 152.39 & 143.7 \\
\hline Proven & 104.71 & 103.35 & 101.54 & 100.26 & 103.35 & 101.22 \\
\hline Potential & 48.74 & 47.35 & 48.85 & 49.04 & 49.04 & 42.84 \\
\hline Production & \multicolumn{7}{|l|}{} & & & \\
\hline$* * *$ Crude Oil (MBOPD) & 952 & 918 & 825 & 789 & 785 & 834 \\
\hline${ }^{* * *}$ Natural gas (MMSCFD) & 8,415 & 7,110 & 6,826 & 8,218 & 8,077 & 695 \\
\hline New contract sign & 21 & 39 & 14 & 7 & 12 & 1 \\
\hline
\end{tabular}

Source: *2012-2016 Oil Proven and Potential Reserves: ESDM

*2012-2016 Gas Proven and Potential Reserves: ESDM

**2012-2016Crude oil production and condensate: ESDM

**2013-2016 Natural gas production: ESDM

***2008-2016 Non-conventional contract sign: ESDM

State revenue from the oil and gas industry from January to December 2016 is US\$9,42 million, US $\$ 5,3$ million from the oil industry and US $\$ 4,1$ million from gas industry. That number meet $86 \%$ targeted state revenue for 2016 which is US $\$ 10,9$ million. The amount is $38 \%$ of total revenue produced from the oil and gas industry. Compared to 2015 , state revenue decreases by $21 \%$, yet followed by cost recovery by 13\% (SKK Migas, 2016). With national energy demand surging on average $7 \%$ annually, but oil and gas production firmly on a downward curve, many are left thinking about whether the Indonesian hydrocarbons industry can ever genuinely rediscover the grandness days of old. In 2015, PT.Pertamina contributing some US $\$ 28,5$ billion in tax and royalties to the treasury. Currently Indonesia ranks 20th out of world oil producers processing roughly $1,1 \%$ of total global production, and 10th largest producer worldwide for gas, second to China in Asia Pacific (Georgescu et al, 2016). According to Indonesian Petroleum Association (IPA) figures, the country's remaining proven, probable and possible (P3) oil reserves stand at a considerable 7,375 million stock tank barrels (MMSTB), while P3 gas reserves amount to a mighty 150 trillion cubic feet (TFC) (IPA, 2015). 
Based on Table 1, the production of crude oil (MBOPD) declining sustainably from 952 thousand barrels of oil equivalent per day in 2011 to 789 thousand barrels of oil equivalent per day in 2015. Thus, in 2016 it increased by 49 thousand barrels of oil equivalent per day to 834 thousand barrels of oil equivalent per day.

Table 2. Oil and Gas Contribution to State Revenue (in Rp. Trillion)

\begin{tabular}{|c|c|c|c|}
\hline Year & $\begin{array}{c}\text { State } \\
\text { Revenue }\end{array}$ & $\begin{array}{c}\text { Oil/Gas } \\
\text { Revenue }\end{array}$ & $\begin{array}{c}\text { \% of } \\
\text { contribution }\end{array}$ \\
\hline 2011 & 1,250 & 193 & $16.02 \%$ \\
\hline 2012 & 1,338 & 205.8 & $15.38 \%$ \\
\hline 2013 & 1,438 & 180.6 & $12.56 \%$ \\
\hline 2014 & 1,538 & 216.9 & $14.11 \%$ \\
\hline 2015 & 1,758 & 78.4 & $4.46 \%$ \\
\hline 2016 & 1,848 & 84.7 & $4.58 \%$ \\
\hline
\end{tabular}

Source: Ministry of Finance (2016).

Based on Table 2, state revenue has been increased, while oil and gas revenue and the percentage have fluctuated between 2014 and 2016 (Daryanto et al,2018). Nonetheless, the amount of oil and gas revenue and the percentage of contribution significantly decline from Rp.216.9 Trillion in 2014 to Rp.78.4 Trillion in 2015. In addition, the percentage of contribution fell from 14.11\% in 2014 to $4.46 \%$ in 2015 . There is slightly increase of oil and gas revenue by Rp.6.3 Trillion became Rp.84.7 Trillion in 2016 and the percentage of contribution increase to $4.58 \%$ in 2016 .

\section{Previous Research on Financial Performance}

The good evaluation method to measure the company performances is the financial ratio, based on Megaladevi (2015). This method usually compares the performance company with competitors. Accounting is one of methods to measure financial performance. (Waddock and Graves 1997; Cochran and Wood 1984) are researchers who use this method. The historical aspects are used to quantify their financial performance (Mcguire, Schneeweis, \& Hill, 1986). Financial performance of oil and gas Company in Indonesia are limited resources ((Daryanto, Nurfadilah, 2018). Based on Tarawneh (2006) Banking industry has applied to examine, evaluate, ranked the financial ratio analysis based on their performance.

\section{Research Model and Hypothesis}

It describes the process of measuring financial performances and examines the differences between the performance of oil and gas industry before and after the decline in oil and gas production. It expands the knowledge with more practical experience.

- H1: Using cash ratio, there is significance difference in financial performance before and after the decline in oil and gas production.

- H2: Using current ratio, there is a significant difference in financial performance before and after the decline in oil and gas production.

- H3: Using a total of equity to total asset ratio, there is significance in financial performance difference before and after the decline in oil and gas industry.

- H4: Using return on equity ratio, there is a significance difference in financial performance before and after the decline in oil and gas production.

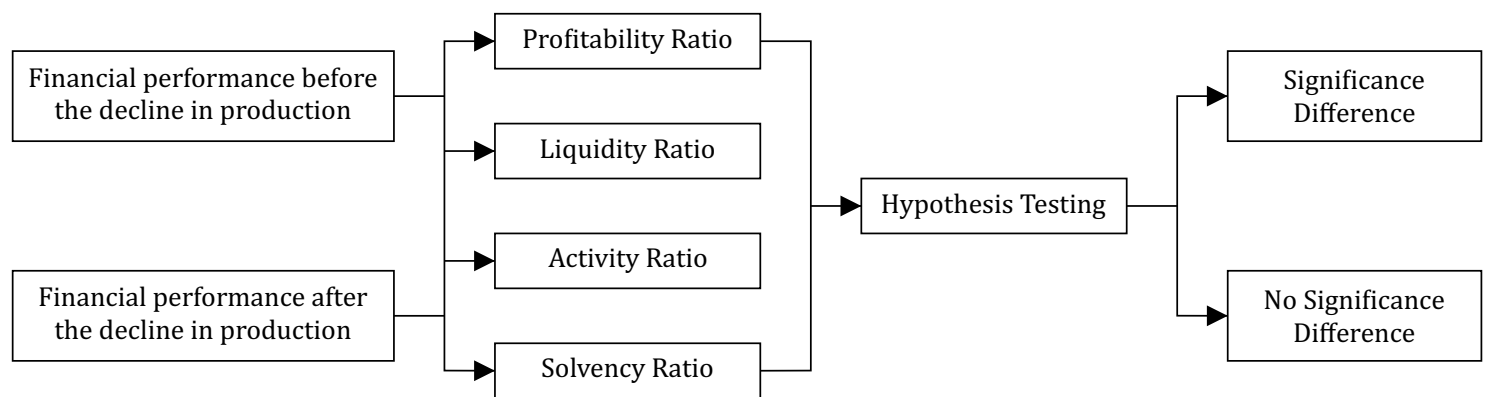

Source: Daryanto, Nurfadilah (2018)

Figure 4. Research model 
- H5: Using return on investment ratio, there is a significance difference in financial performance before and after the decline in oil and gas production.

- H6: Using investment turnover ratio, there is a significance difference in financial performance before and after the decline in oil and gas production.

- H7: Using total asset turnover, there is a significance difference in financial performance before and after the decline in oil and gas production.

- H8: Using collection period ratio, there is a significance difference in financial performance before and after the decline in oil and gas production.

\section{METHODOLOGY}

The descriptive financial ratio analysis was used to analyze the financial performance of Indonesia's private oil and gas company before and after declining the national oil and gas production during the period of 2011 to 2016. Then, Paired sample t-test also used to examine the significance differences in the period of before (2011 to 2013) and after (2014 to 2016) declining in national oil and gas production. Paired sample $t$-test is a statistical technique to use in before-after studies to compare two population means (Daryanto, Nurfadilah, 2018). PT Medco Energi Internasional Tbk is selected because it is the market leader of Oil \& Gas private company in Indonesia. In this study, data were collected from Annual Report (audited) from 2011 until 2016. The variables are included profitability ratio, liquidity ratio, activity ratio and solvency ratio.

\section{Profitability Ratio}

Profitability is measured using the criteria as

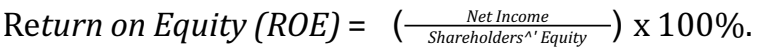
Return on equity (ROE) indicates the company's profitability and growth potential. In addition, return on investment (ROI) is a profitability ratio that calculates the profits of an investment as a percentage of the original cost. The equation of ROI can be expressed as Return on Investment (ROI) = ( $\left.\frac{\text { Total Revenue-Total Cost }}{\text { Capital Employed }}\right) \times 100 \%$. ROI show the ability of the company to measure the income generated on investment relative to the amount of money invested.

\section{Liquidity Ratio}

The liquidity ratio measures the company ability to pay its short-term debt. It can be expressed as Cash Ratio ( $\left.\frac{\text { Cash }+ \text { Cash Equivalents }}{\text { Current Liabilities }}\right) \times 100 \%$. Cash ratio measures the liquidity of the company to pay the current liabilities with only cash and cash equivalents. In addition, it measures the company ability to repay its current liability with current asset as expressed as Current Ratio = $\left(\frac{\text { Current Asset }}{\text { Current Liabilities }}\right) \times 100 \%$. The current ratio measures the company ability to pay its short-term and longterm liabilities using their short-term assets.

\section{Activity Ratio}

The activity ratios measure the efficiency of the company in using its resources. First, Collection Period $=\left(\frac{\text { Average Accounts Receivables }}{\text { Sales Revenue }}\right) \times 365$ days. It is an important indicator to monitor their cash flow and collect a debt from customers. If the companies have high collection period, they should communicate with their customers regarding debts. Second, Inventory Turnover $=\left(\frac{\text { Cost of Goods Sold }}{\text { Average Inventory }}\right)$. This ratio measures how many times the inventory is being sold of a certain period of time. If the ratio is high, it indicates that the inventory level is inadequate. If the ratio is low, it indicates that the company is overstocking and deficiencies in the marketing effort. Third, Total Asset Turnover $=\left(\frac{\text { Revenue }}{\text { Capital Employed }}\right) \times 100 \%$. This ratio measures the company ability to measure the efficiency to use its asset to generate sales. It indicates the company ability to generate revenue from deploying its asset. A higher ratio indicates that company using its assets more efficiently and lower ratio indicate that company is using its asset deficiently.

\section{Solvency Ratio}

This ratio measures the percentage of company's asset owned by investors and the leverage level of the company with its debt. It can be expressed as Total Equity to Total Asset $=\left(\frac{\text { Total Equity }}{\text { Total Asset }}\right) \times 100 \%$.

\section{RESULT AND DISCUSSION} Profitability Performance

Figure 5 shows the percentage of return on 
investment (ROI) and return on equity (ROE) in PT Medco Energi Internasional Tbk between 2011 and 2016.

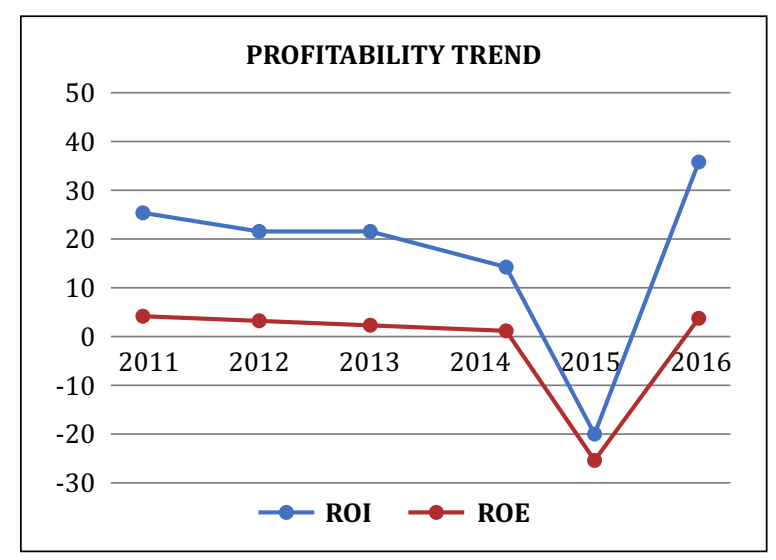

Figure 5. Profitability Trend

It shows that percentage of ROE decreased slightly from 2012 -2014, from $2.24 \%$ to $1.49 \%$. There was significant decrease of ROE from $2014-2015$, from $1.49 \%$ to $-26.54 \%$ because in 2015 Medco suffered considerable losses impact from declining oil price. In ROI the trend almost the same with ROE, in 2011 to 2013 there was slightly decline from $24.62 \%$ to $21.55 \%$ but in 2013 to 2014 there was significant decline from $21.55 \%$ to $12.05 \%$, but biggest decline was 2014 to 2015 , from $12.05 \%$ to $-20.86 \%$. In 2016 ROI increase become $37.1 \%$, it causes Medco increased production from $56 \mathrm{MBOPD}$ to $66 \mathrm{MBOPD}$ and decreasing cash cost operational per unit from US\$12.3 per BOE to US\$8.8 per BOE.

\section{Liquidity Performance}

Figure 6 below gives the information about the percentage of cash ratio and current ratio of PT. Medco Energi Internasional Tbk. between 2011 to 2016.

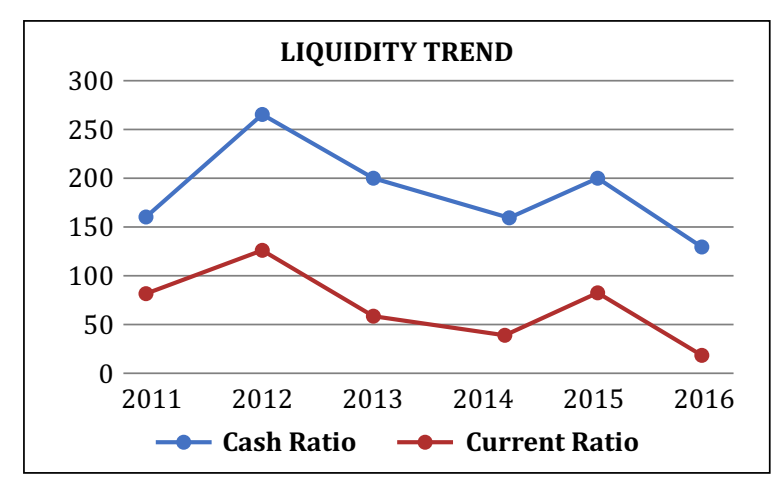

Figure 6. Liquidity Trend
Overall cash ratio fluctuated occurred, in 2011 to 2012 increasing from $86.74 \%$ to $121.16 \%$, then decreasing in 2013 to $64.37 \%$, then increasing again to $87.95 \%$ in 2015 , and finally decreasing to $19.12 \%$ in 2016 . The current ratio is main indicator to quantify the liquidity of company (Daryanto et. al, 2017). The average current ratio in horizontal analysis for the past six years was $186.08 \%$ which means US\$ 1.8608 of current assets can guarantee US\$ 1.0 of current liability. The highest current ratio was $264.86 \%$ in 2012, In 2011 was $160.51 \%$. The lowest current ratio was $131.80 \%$ in 2016.

\section{Activity Performance}

This graph below shows information about the percentage of the number of collection period, total assets turnover and inventory turnover from PT. Medco Energi Internasional Tbk. The percentage of total assets turnover (TATO) decreasing every year, in 2011 was $146.99 \%$ to $118.45 \%$ in 2016, similarly with inventory turnover (ITO) in 2011 was 14.12 times to 6.01 times in 2016. The collection period increased every year from 88.45 days in 2011 to 134.65 days in 2016. Management was less effective in managing inventory.

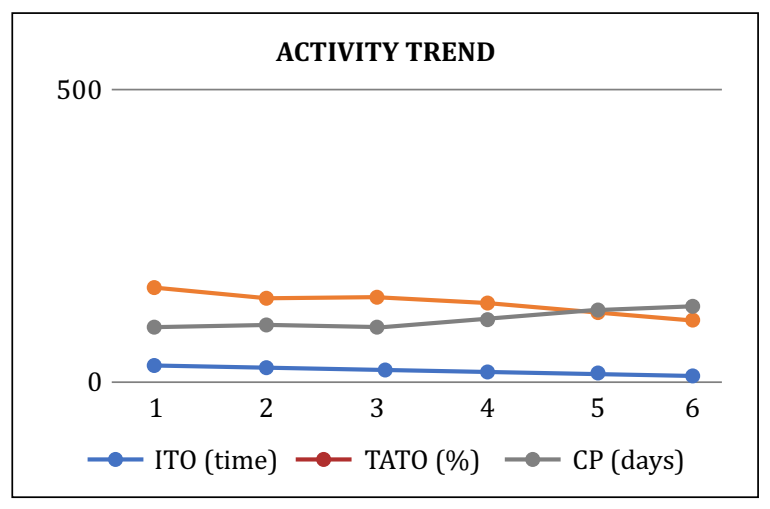

Figure 7. Activity Trend

\section{Solvency Performance}

The line chart below was the percentage of total equity to total assets ratio (TETA) in PT MEDCO INTERNASIONAL TBK between 2011 and 2016. In 2011 - 2014 TETA was between $33 \%$ to $35 \%$, but in 2015 decreasing to $24.11 \%$, similarly in 2016 was $24.75 \%$. The average (TETA) from 2011 to 2016 was $31.10 \%$ that indicates Medco is insolvent 
because $50 \%$ is general standard (Daryanto, et. al, 2017). Medco should increase profit every year to mitigate the risks.

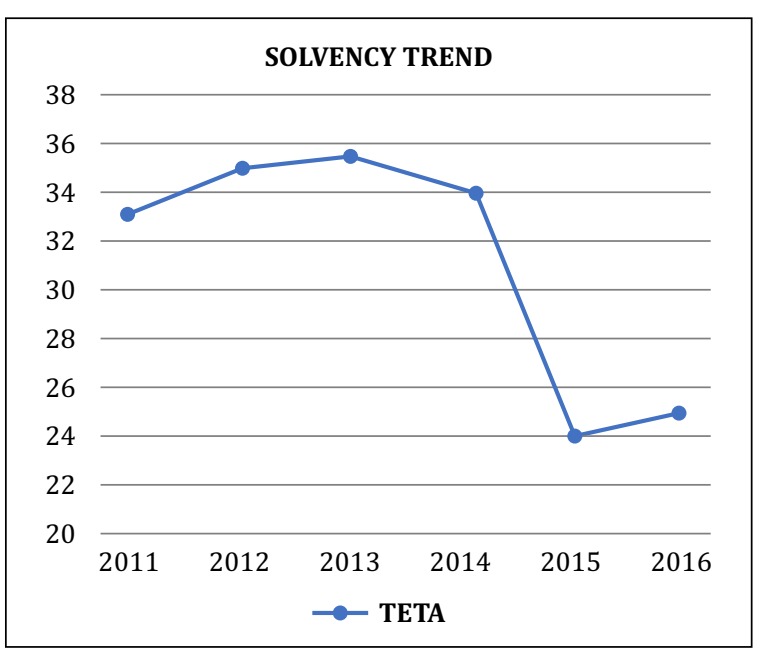

Figure 8. Solvency Trend

\section{Hypothesis Testing}

Table 3 is result from paired sample $t$-test. The results are three hypotheses are accepted and five hypotheses are rejected. Cash ratio has huge difference between the mean before and after oil and gas crisis with the $\mathrm{P}$ - value $\leq \alpha(0.004<0.05)$ and $t$ - value $(-2.0)$, the inventory turnover has huge difference between before and after, with the $\mathrm{P}$-value $\leq \alpha(0.034<0.05)$ and $\mathrm{t}$ - value (3.63), and the last hypothesis that accepted is collection period with the $\mathrm{P}$-value $\leq \alpha(0.033<0.05)$ and $\mathrm{t}$ value $(-3.73)$. It means there are effect of failing oil prices and decreasing oil production. We refuse the total assets to turnover with P-value $\leq \alpha(0.989<0.05)$ and $t$-value (3.41), return on Investment with $\mathrm{P}$-value $\leq \alpha(0.257>005)$, Return on equity with P-value $\leq \alpha(0.22>0.05)$, total equity to total assets with P-value $\leq \alpha(0.105>$ $0.05)$ and current ratio with P-value $\leq \alpha(0.092>$ 0.05). So, TETA, TATO, current ratio, ROI and ROE are rejected.

\section{CONCLUSION}

After measuring financial performance of Indonesia's private Oil and Gas Company before (2011 - 2013) and after decline in oil and gas production (2014-2015) nationally. This research discovers that the financial performance of PT. MEDCO ENERGI INTERNASIONAL TBK for six years quite good, even though in 2015 suffered considered loss, but in 2016 Medco can rise up.

Table 3. Paired Sample t-Test

\begin{tabular}{|c|c|c|c|c|c|}
\hline Description & Period & Means & $\begin{array}{c}\text { Std. } \\
\text { Deviation }\end{array}$ & $\begin{array}{c}\text { Paired } \\
\text { Sample t-test }\end{array}$ & Decision \\
\hline \multirow{2}{*}{ Cash Ratio } & Before & 90.7 & 28.6 & \multirow{2}{*}{0.004} & \multirow{2}{*}{ Accept } \\
\hline & After & 50.4 & 34.8 & & \\
\hline \multirow{2}{*}{ Current Ratio } & Before & 208.5 & 52.6 & \multirow{2}{*}{0.092} & \multirow{2}{*}{ Reject } \\
\hline & After & 163.6 & 33.4 & & \\
\hline \multirow{2}{*}{ ROI } & Before & 22.5 & 1.8 & \multirow{2}{*}{0.257} & \multirow{2}{*}{ Reject } \\
\hline & After & 9.4 & 29.1 & & \\
\hline \multirow{2}{*}{ TETA } & Before & 34.56 & 1.04 & \multirow{2}{*}{0.105} & \multirow{2}{*}{ Reject } \\
\hline & After & 27.64 & 5.56 & & \\
\hline \multirow{2}{*}{ ROE } & Before & 2.03 & 0.23 & \multirow{2}{*}{0.22} & \multirow{2}{*}{ Reject } \\
\hline & After & -7.28 & 16.7 & & \\
\hline \multirow{2}{*}{ ITO } & Before & 14.07 & 0.05 & \multirow{2}{*}{0.034} & \multirow{2}{*}{ Accept } \\
\hline & After & 8.89 & 2.5 & & \\
\hline \multirow{2}{*}{ TATO } & Before & 140.4 & 5.86 & \multirow{2}{*}{0.989} & \multirow{2}{*}{ Reject } \\
\hline & After & 123.83 & 5.23 & & \\
\hline \multirow{2}{*}{$\mathrm{CP}$} & Before & 89.92 & 1.24 & \multirow{2}{*}{0.033} & \multirow{2}{*}{ Accept } \\
\hline & After & 122.4 & 16.24 & & \\
\hline
\end{tabular}


Wiwiek Mardawiyah Daryanto, Sudarmawan Samidi / A Financial Ratio Analysis of Oil and Gas Private Company in Indonesia: Before and After Declining the Oil Production / 74- 83

Three ratios are significantly different in period before and after decline oil and gas production nationally such as cash ratio, inventory ratio, and collection period. Five the others ratio such as current ratio, return on investment, return on equity, total equity to total assets, and total assets turnover are not significant different from before and after decline oil and gas production nationally.

\section{RE F EREN C ES}

Bentley, R. W. (2002). Global oil \& gas depletion: an overview. Energy policy, 30(3), 189-205.

Daryanto, W.M., and Nurfadilah, D. (2017). Financial Performance Analysis in Oil and Gas Industry: Empirical Evidence from Indonesia. International Journal of Engineering \& Technology, 7(3.21), 10-15.

Dutta, S. (2013). Introduction to Oil and Gas Industry. Retrieved from https://www.oilandgasiq.com /strategy-management-and-information/articles/oil-gas-industry-an-introduction

Cochran, P. L., \& Wood, R. A. (1984). Corporate social responsibility and financial performance. Academy of managementJournal, 27(1), 42-56.

Gensler, L. (2017). The World's Largest Oil and Gas Companies 2017: Exxon Reigns Supreme, while Chevron Slips.Retrieved from https://www.forbes.com/sites/laurengensler/2017/05/24/the-worldslargest-oil-and-gas-companies-2017-exxon-mobil-reigns-supreme-chevronslips/\#47d955724f87

Georgescu, M., Haynes, L., Höck, R., and Peemoeller, J. (2016). Indonesia: Striving for a comeback. Oil \& Gas Financial Journal. Retrieved from http://www.ogfj.com/articles/print/volume-13/issue4/features/focus-report-indonesia/indonesia-striving-for-a-comeback.html

Indonesian Petroleum Association (IPA). (2015). Retrieved from http://ipa.or.id/

Industry Migas. (2011). Oil and Gas Industry in Indonesia. Retrieved from http://www.industrimigas.com /2012/01/sejarah-perkembangan-industri-migas-di.html

IPP Journal. (n.d). PT. Medco Power Indonesia. Retrieved from http://www.ippjournal.com/company/ptmedco-power-indonesia

McGuire, J., Schneeweis, T., \& Hill, J. (1986). An analysis of alternative measures of strategic performance. Advances in strategic management, 4(2), 1986.

Megaladevi, P. (2015). A study on inancial performance analysis of the selected paper company with special reference to Tamil Nadu Newsprint and papers limited. International Journal of Recent Research Aspects, 2(4), 22-24.

Medcopower. (2017). Medcoenergi Strengthen ownership in power business. Retrieved from http:// medcopower.co.id/news_and_media/detail/medcoenergi_strengthen_ownersh

Ministry of Energy and Mineral Resources of Republic of Indonesia. (2016). ICP Juni 2016 Turun Jadi US $\$ 44,50$ per Barrel. Retrieved from https://www.esdm.go.id/en/media- center/newsarchives/icp-juni-2016-turun-jadi-us-4450-per-barel

Ministry of Energy and Mineral Resources of Republic of Indonesia. (2016). Produksi dan Pemanfaatan Gas Bumi. Retrieved from http://statistik.migas.esdm.go.id/index.php?r=pengolahanNaturalGas/index

Ministry of Energy and Mineral Resources of Republic of Indonesia. (2016). Produksi Minyak Bumi dan Kondensat. Retrieved from http://statistik.migas.esdm.go.id/index.php?r=produksiMinyak Mentah/index

Ministry of Energy and Mineral Resources of Republic of Indonesia. (2016). Cadangan Minyak Bumi. Retrieved from http://statistik.migas.esdm.go.id/index.php?r=cadanganMinyakBumi/index

Ministry of Energy and Mineral Resources of Republic of Indonesia. (2016). Cadangan Gas Bumi. Retrieved from http://statistik.migas.esdm.go.id/index.php?r=cadanganGasBumi/index 
Ministry of Energy and Mineral Resources of Republic of Indonesia. (2016). Penandatanganan Wilayah Kerja Non Konvensional. Retrieved from http://statistik.migas.esdm.go.id/index.php?r=non Konvensional/index

OPEC. (2016). Retrieved from http://www.opec.org

PWC. (2017). Oil and Gas in Indonesia. Investment and Taxation Guide. Retrieved from https://www.pwc.com /id/en/energy-utilities-mining/assets/oil\%20and\%20gas/oil-and-gas-guide-2017.pdf

SKK Migas. (2016). Laporan Tahunan 2016 SKK Migas. Retrieved from http://skkmigas.go.id/images/ upload/file/AR_SKK_MIGAS_INDO_2016.pdf

Statistica. (2016). Global oil industry and market. Retrieved from https://www.statista.com/study/10750/ global-oil-industry-and-market-statista-dossier/

Tarawneh, M. (2006). A comparison of financial performance in the banking sector: Some Evidence from Omani Commercial Banks. International Research Journal of Finance and Economics, 3(3), 101-112.

Waddock, S. A., \& Samuel B. Graves. (1997). The corporate social performance-financial performance link. Strategic Management Journal, 18(4),303-319. 